\title{
Transdifferentiation of Mature Rat Hepatocytes into Bile Duct-Like Cells in Vitro
}

\author{
Yuji Nishikawa, ${ }^{*}$ Yuko Doi, ${ }^{\dagger}$ Hitoshi Watanabe, ${ }^{\dagger}$ \\ Takuo Tokairin, ${ }^{*}$ Yasufumi Omori, ${ }^{*} \mathrm{Mu} \mathrm{Su},{ }^{*}$ \\ Toshiaki Yoshioka, ${ }^{*}$ and Katsuhiko Enomoto* \\ From the Department of Pathology and Immunology* and \\ Central Research Laboratory, ${ }^{\dagger}$ Akita University School of \\ Medicine, Akita, Japan
}

We investigated the mechanism of phenotypic plasticity of hepatocytes in a three-dimensional organoid culture system, in which hepatocytic spheroids were embedded within a collagen gel matrix. Hepatocytes expressed several bile duct markers including cytokeratin (CK) 19 soon after culture and underwent branching morphogenesis within the matrix in the presence of insulin and epidermal growth factor. Cultured hepatocytes did not express Delta-like, a specific marker for oval cells and hepatoblasts. Furthermore, hepatocytes isolated from c-kit mutant rats (Ws/Ws), which are defective in proliferation of oval cells, showed essentially the same phenotypic changes as those isolated from control rats. The bile duct-like differentiation of hepatocytes was associated with increased expression of Jagged1, Jagged2, Notch1, and several Notch target genes. CK19 expression and branching morphogenesis were inhibited by dexamethasone, a mitogen-activated protein kinase kinase 1 (MEK1) inhibitor (PD98059), and a phosphatidyl inositol 3-kinase inhibitor (LY294002). After being cultured for more than 3 weeks within the gels, hepatocytes transformed into ductular structures surrounded by basement membranes. Our results suggest that hepatocytes might have the potential to transdifferentiate into bile duct-like cells without acquiring a stem-like phenotype and that this is mediated through specific protein tyrosine phosphorylation pathways. (Am J Patbol 2005, 166:1077-1088)

Bile ductules are known to increase in the portal area in chronic liver disease associated with portal fibrosis and inflammation. This tissue reaction has been referred to as the atypical ductular reaction, which can be distinguished from the typical ductular reaction because of regular proliferation of pre-existing bile duct cells seen in acute biliary obstruction. ${ }^{1,2}$ The progressive permeation of the liver lobules by irregular ductular structures appears to further hamper the function of the liver.

The cellular origin of the newly formed bile ductules in the atypical ductular reaction has been a subject of debate. It has been speculated that emergent ductules in the reaction might be derived from putative liver stem cells. ${ }^{3,4}$ Liver stem cells include transit-amplifying ductular cells (oval cells) and periductal stem cells, which reside in the terminal bile ductules and periductal areas of the adult liver, respectively. ${ }^{4-6}$ They are considered to be bipotential (having a capacity to differentiate into both hepatocytes and bile ductular cells) or multipotential, and some of them might be derived from the bone marrow. Although mature hepatocytes have an extensive selfrenewal capacity during liver injury and are regarded as functional stem cells, ${ }^{7-9}$ it has been generally supposed that their phenotype is fixed, thereby constituting a unipotential stem cell system. ${ }^{5,6}$ However, as discussed extensively by Desmet and colleagues, ${ }^{1}$ it is also possible that at least some types of ductular reaction might be because of metaplastic differentiation of mature hepatocytes into bile ductules (ductular metaplasia).

We previously reported that aggregates of adult rat hepatocytes cultured within type I collagen gels underwent branching morphogenesis with expression of bile duct-specific cytokeratin (CK) 19. ${ }^{10}$ Other investigators also provided evidence of possible phenotypic changes of mature hepatocytes to bile duct-like cells. ${ }^{11-15}$ Although these data strongly suggest the bipotentiality of mature hepatocytes, the detailed process and mechanism of the transformation have not been described, and true bile ductular structures, ie, small round ductules surrounded by basement membranes, have not been demonstrated to appear in hepatocytic cultures. Furthermore, it has not been clear whether these changes are transdifferentiation of hepatocytes to bile duct cells, or are mediated by dedifferentiation of hepato-

Supported in part by the Ministry of Education, Science, Sports, and Culture of Japan (grants 11670203 and 13670204)

Accepted for publication January 11, 2005

Address reprints requests to Yuji Nishikawa, Department of Pathology and Immunology, Akita University School of Medicine, 1-1-1 Hondo, Akita 010-8543, Japan. E-mail: nishikwa@med.akita-u.ac.jp. 
cytes to more primitive (stem-like) cells, such as oval cells or hepatoblasts.

In the present study, we have shown that hepatocytes express several bile duct markers, including CK19, soon after being cultured, but they do not express Delta-like, a recently identified marker for oval cells and hepatoblasts. ${ }^{16,17}$ We have also suggested that transdifferentiation of hepatocytes is associated with the activation of the Notch signaling pathway, which is crucial in normal bile duct differentiation, ${ }^{18}$ and that bile duct-like differentiation is dependent on specific protein tyrosine phosphorylation pathways, such as those mediated by MEK1 and PI 3 kinase. Finally, we have demonstrated that hepatocytes actually form round ductular structures, which are morphologically and immunocytochemically indistinguishable from bile ductules, within type I collagen gels in long-term cultures.

\section{Materials and Methods}

\section{Isolation and Culture of Rat Hepatocytes}

Hepatocytes of male F344 rats (6 to 10 weeks old) were isolated by the two-step collagenase perfusion method, followed by repeated low-speed centrifugation at $70 \times g$. Isolated hepatocytes were plated onto positively charged plastic dishes (Primaria; Becton-Dickinson Labware, Franklin Lakes, $\mathrm{NJ}$ ) to form spheroidal aggregates. In some experiments, cells were also plated on collagencoated plastic dishes. Cells were cultured in serum-free Williams' E medium supplemented with $10 \mathrm{mmol} / \mathrm{L}$ nicotinamide, $10 \mathrm{ng} / \mathrm{ml}$ mouse epidermal growth factor (EGF) (Roche Diagnostics, Mannheim, Germany), and $10^{-7}$ $\mathrm{mol} / \mathrm{L}$ insulin (Sigma Chemical Company, St. Louis, MO). After 4 or 5 days, formed spheroidal aggregates were harvested and used for three-dimensional cultures. In some experiments, periportal and perivenular hepatocytes were selectively isolated by the digitonin-collagenase perfusion technique. ${ }^{19}$ Hepatocytes were also isolated from Ws/Ws rat, a mutant for the c-kit receptor tyrosine kinase ${ }^{20}$ that is known to be defective in oval cell proliferation. ${ }^{21}$

Three-dimensional cultures of hepatocytic spheroids within the collagen gel matrix were performed using a type I collagen solution (Cellmatrix Type I-A; Nitta Gelatin, Osaka, Japan) as described previously. ${ }^{10}$ After embedding the spheroidal aggregates within the matrix, cells were cultured in Williams' E medium supplemented with $10 \mathrm{mmol} / \mathrm{L}$ nicotinamide and 10\% fetal bovine serum (standard medium), with or without insulin $\left(10^{-7} \mathrm{~mol} / \mathrm{L}\right)$ and EGF $(10 \mathrm{ng} / \mathrm{ml})$. To examine the effects of increased protein tyrosine phosphorylation on hepatocytic differentiation, a protein tyrosine phosphatase inhibitor, sodium orthovanadate (OV; Wako Pure Chemical Industries, Osaka, Japan) was added to the medium at various concentrations. In some experiments, dexamethasone (Sigma), a specific mitogen-activated protein kinase kinase 1 (MEK1) inhibitor (PD98059; Cell Signaling, Beverly, MA), or a phosphatidyl inositol (PI) 3-kinase inhibitor
(LY294002; Cell Signaling) was also added to the medium.

To examine the presence of ductular structures, longterm cultured cells within the collagen gels were fixed in acetic acid-ethanol (1:99), paraffin-embedded, sectioned, and stained with hematoxylin and eosin (H\&E). For observation of the ultrastructures, cells were fixed with $2.5 \%$ glutaraldehyde and $1 \%$ osmium tetroxide, and embedded in Epon resin. Ultrathin sections were stained with uranylate and lead and observed under an electron microscope (JEOL, Tokyo, Japan).

\section{Western Blot Analysis}

Gels containing cells were washed with phosphate-buffered saline and homogenized in a lysis buffer ( $1 \%$ Triton X-100, $1 \%$ sodium deoxycholate, $0.1 \%$ sodium dodecyl sulfate, $158 \mathrm{mmol} / \mathrm{L}$ sodium chloride in $10 \mathrm{mmol} / \mathrm{L}$ Tris- $\mathrm{HCl}$ buffer, $\mathrm{pH}$ 7.5) containing protease inhibitors. Protein samples were also prepared from the nonparenchymal cells, which were present in the supernatant after the first low-speed centrifugation during hepatocyte isolation, and undigested portal tissues. Samples (40 $\mu \mathrm{g}$ protein per lane) were subjected to sodium dodecyl sulfate-polyacrylamide gel electrophoresis using $10 \%$ polyacrylamide gels, and then transferred to polyvinylidene difluoride membranes. Primary antibodies used were anti-albumin (rat-specific; Nordic Immunological Laboratories, Tilburg, Netherlands), anti-CK19 (AmershamPharmacia Biotech UK, Buckinghamshire, UK), anti-CK8 (American Research Products, Belmont, MA), anti-CK20 (Biomeda, Foster City, CA), anti-proliferating cell nuclear antigen (PCNA) (Santa Cruz Biotechnology, Santa Cruz, $\mathrm{CA}$ ), anti-hepatocyte nuclear factor (HNF)-1 (Santa Cruz), anti-HNF- $4 \alpha$ (Santa Cruz), anti-SE-1 (a specific antibody against rat sinusoidal endothelial cells), ${ }^{22}$ PY-20 (TaKaRa, Ohtsu, Japan), and anti-actin (Sigma) antibodies. Detection was performed with enhanced chemiluminescence reagents (Amersham-Pharmacia Biotech UK).

\section{Reverse Transcriptase-Polymerase Chain Reaction (RT-PCR)}

We examined gene expression of several hepatocytic and bile duct markers, as well as deleted in malignant brain tumor 1 (DMBT1), a marker for atypical bile ductular reaction, ${ }^{23}$ and Delta-like, a marker for oval cells and hepatoblasts, ${ }^{16,17}$ in cultured hepatocytes by RT-PCR. We also examined gene expression of the ligands, receptors, and primary targets of the Notch signaling system, which is thought to be crucial in the development of intrahepatic bile ducts. ${ }^{24-26}$ Glyceraldehyde 3-phosphate dehydrogenase (GAPDH) mRNA was amplified to evaluate the input RNA for each reaction. Total RNA from hepatocytes and portal tissues was prepared by using TRIzol reagent (Life Technologies, Grand Island, NY). A one-step RT-PCR kit (TaKaRa) was used for the reaction, in which RNA $(0.5 \mu \mathrm{g})$ was reverse-transcribed using AMV reverse transcriptase for 30 minutes and then am- 
plified for 25 cycles of 95,60 , and $72^{\circ} \mathrm{C}$ for 30,30 , and 90 seconds.

The specific primers used and the expected fragment sizes were as follows. Albumin: forward, 5'-TTGCCAAGTACATGTGTGAG-3'; reverse, 5'-GGTTCTTCTACAAGAGGCTG-3'; 373 bp. Transthyretin: forward, 5'-GGGTAGAACTGGACACCAAATC-3'; reverse, 5'-AGAACGTTTCACGGCATCTTCC-3', 294 bp. CYP2B2: forward, 5'GAGTTCTTCTCTGGGTTCCTG-3'; reverse, 5'-ACTGTGGGTCATGGAGAGCTG-3'; 550 bp. CYP8B1: forward, 5' AGCACGCAGAAAGTGCTAGAC-3'; reverse, 5'-TGTCCTTGGTGCAGCCAAACA-3'; 301 bp. CK19: forward, 5'GACTTCCTATAGCTATCGCC-3'; reverse, 5'-TCTGGTACCAGTCGCGAATC-3'; 359 bp. Glutathione S-transferase placental form (GST-P): forward, 5'-TCAAGTCCACTTGTCTGTATG-3'; reverse, 5'-CTGTTTACCGCCGTTGAT-3'; 500 bp. DMBT1: forward, 5'-GGCACAAATAACGATGTGTCC-3'; reverse, 5'-AGTTGTCCACCAATCGGCTAT-3';510bp. $\alpha$-Fetoprotein(AFP):forward, $5^{\prime}$-TGAAATTTGCCACGAGACGG -3'; reverse, 5'-TGTCATACTGAGCGGCTAAG-3'; $272 \mathrm{bp}$ (specific to the $2.1 \mathrm{~kb}$ transcript). ${ }^{27}$ Delta-like (preadipocyte factor 1): forward, 5'-ATGTCTGCAGGTGTGAGCCTG-3'; reverse, 5'-GGCTTGCACAGACACTCGAAG-3'; 599 bp. Jagged1: forward, 5'-TCCAGCCTCCAGCCAGTGAA-3'; reverse, 5'GGAAGGCTCACAGGCTATGT-3'; 201 bp. ${ }^{24}$ Jagged2: forward, 5'-ACATGCTATGACAGCGGCGA-3'; reverse, 5' CCAGGAACTCCCATGTGGGA-3'; 480 bp. Notch1: forward, 5'-ATCCATGGCTCCATCGTCTA-3'; reverse, 5' TTCTGATTGTCGTCCATCAG-3'; 422 bp. Notch2: forward, 5'-TTTGCTGTCGGAAGACGACC-3'; reverse, 5'-GCCCATGTTGTCCTGGGCGT-3'; 403 bp. Notch3: forward, 5'-TTCCAGATTCTCATCAGGAA-3'; reverse, 5'-TCCTGGTGGGCAGAGCAATG-3'; 480 bp. Hes (hairy/enhancer of split) 1: forward, 5'-CAACACGACACCGGACAAACC3'; reverse, 5'-AGTGCGCACCTCGGTGTT-AAC-3'; 349 bp. Hes2: forward, 5'-CTTCTGTTTTCGCT-CTGCCTT-3'; reverse, 5'-TCGAGGTAGCTATCCAA-AGAC-3'; 352 bp. Hes3: forward, 5'-TCAGCATCTTTAT-CAGGCCTC-3'; reverse, 5'-CTAGCCAAAGTCCTTGC-AATG-3'; 302 bp. Hes5: forward, 5'-CAAGGAGAAAAA-TCGACTGCG-3'; reverse, 5'-ATGCAGGGTCAGGAACT-GCAC-3'; 280 bp. HERP (Hes-related repressor protein) 1: forward, 5'ACCCAATGGACTCCACACATC-3'; reverse, 5'-TGTTCCACTGCTTGTCTGCTG-3'; 379 bp. HERP2: forward, 5'GAGATCTTGCAGATGACTGTG-3'; reverse, 5'-TGTCGAAGGACTCAGTAGATG-3'; 561 bp. GAPDH: forward, 5'ACCACAGTCCATGCCATCAC-3'; reverse, 5'-TCCACCACCCTGTTGCTGTA-3'; 452 bp.

\section{Immunocytochemistry and Lectin Cytochemistry}

Immunocytochemistry for albumin, CK19, CK7, laminin, type IV collagen, Notch1, and Jagged1 was performed on paraffin sections of cells embedded within the gels. The primary antibodies used were as follows. Anti-albumin (Nordic Immunological Laboratories), anti-CK19 (mouse monoclonal, 1:200 dilution; Amersham-Pharmacia Biotech UK), anti-CK7 (mouse monoclonal, 1:20 dilution; ICN Pharmaceuticals, Aurora, $\mathrm{OH}$ ), anti-laminin (rab-
A
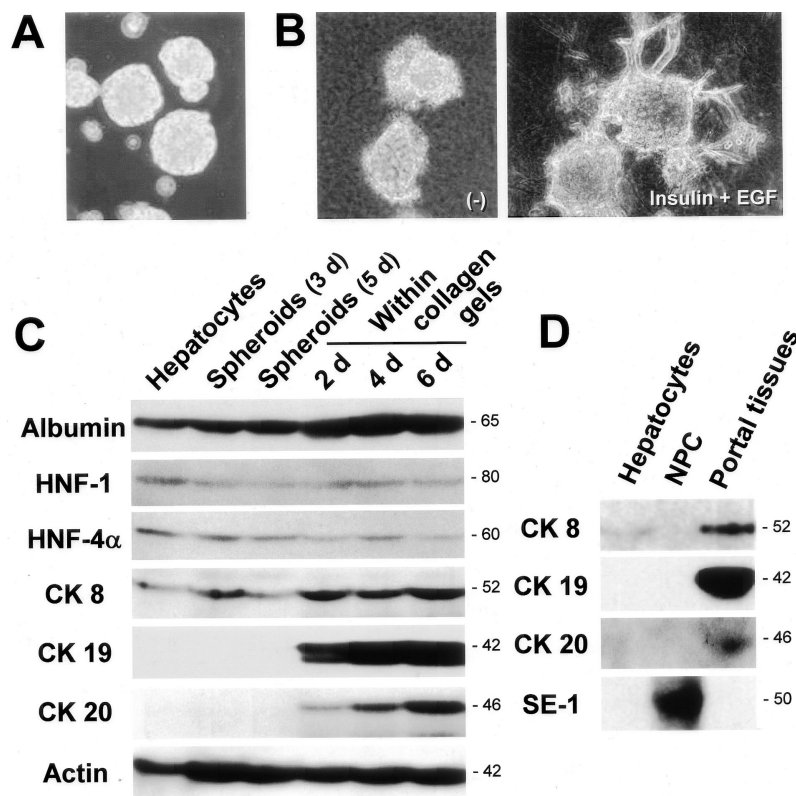

Figure 1. Branching morphogenesis and bile duct-specific CK expression in the three-dimensional cultures of hepatocytes within a collagen gel matrix. A: Spheroidal aggregates of isolated hepatocytes on positively charged plastic dishes ( 3 days after culture). Phase-contrast microscopy. Original magnification, $\times 25$. B: Spheroidal aggregates cultured for 7 days within the matrix in the absence (left) or presence (right) of insulin $\left(10^{-7} \mathrm{~mol} / \mathrm{L}\right)$ and EGF (10 $\mathrm{ng} / \mathrm{ml}$ ). Phase-contrast microscopy. Original magnification, $\times 25$. C: Western blot analyses for the expression of albumin, HNF-1, HNF- $4 \alpha$, CK8, CK19, CK20, and actin in hepatocytes at various time periods after culture in the presence of insulin $\left(10^{-7} \mathrm{~mol} / \mathrm{L}\right)$ and EGF $(10 \mathrm{ng} / \mathrm{ml})$. D: Western blot analyses for the expression of CK8, CK19, CK20, and SE-1 (sinusoidal endothelial cell marker) in freshly isolated hepatocytes, nonparenchymal cells, and portal tissues.

bit polyclonal, 1:1000 dilution, LSL; Cosmo Bio, Tokyo, Japan), anti-collagen type IV (mouse monoclonal, 1:100; Chemicon, Temecula, CA), anti-Notch1 (goat polyclonal, 1:100 dilution, C-20; Santa Cruz), and anti-Jagged1 (rabbit polyclonal, 1:100 dilution, H-114; Santa Cruz). Detection was performed with Envision+ system HRP (DAKO, Carpinteria, CA) for albumin, CK19, CK7, laminin, collagen type IV, and Jagged1, and with ImmunoCruz staining system (Santa Cruz) for Notch1. Cells in paraffin sections were also examined for binding sites of Dolichos biflorus agglutinin, a bile duct-specific lectin, using biotin-conjugated Dolichos biflorus agglutinin (EY Laboratories, San Mateo, CA).

\section{Results}

\section{Branching Morphogenesis and Expression of Bile Duct-Specific CK in Cultured Hepatocytes}

After plating on Primaria dishes, isolated hepatocytes formed spheroidal aggregates within 3 days (Figure 1A). After being embedded within a collagen gel matrix, hepatocytes began to extend cellular processes into the matrix and, after 7 days, some of the spheroids showed a branching morphology in the presence of insulin and EGF, but not in the absence of these factors (Figure 1B).

We examined the expression of several hepatocytic markers and $\mathrm{CK}$ in hepatocytes cultured within the col- 
lagen gels by Western blot analysis. Hepatocytic markers (albumin, HNF-1, and HNF-4 $\alpha$ ), as well as CK8, which is known to be normally expressed in hepatocytes, were expressed in the spheroids either before or after being embedded within the gels (Figure 1C). Although there was no detectable protein expression of CK19 and CK20, another bile duct-specific CK, ${ }^{28}$ in freshly isolated hepatocytes and 3-day- and 5-day-cultured spheroids, the cells in the spheroids began to express both CKs 2 days after being embedded within the collagen gel matrix (Figure 1C). A total period of 7 days in culture was necessary to obtain a detectable level of protein expression of the bile duct-specific CK, irrespective of culture forms (monolayer, spheroid, or collagen gel cultures) (data not shown). Actin was expressed in both freshly isolated and cultured hepatocytes, whereas there was an increase in expression after culture (Figure 1C). As shown in Figure 1D, bile duct-specific CK19 expression was found in the portal tissues (containing bile ducts and blood vessels), but absent in freshly isolated hepatocytes and a nonparenchymal cell fraction (containing Kupffer cells, stellate cells, and sinusoidal endothelial cells). CK8 was detected in both hepatocytes and portal tissues, and expression of the specific endothelial cell marker, SE-1,22 was only found in the nonparenchymal cell fraction (Figure 1D).

\section{There Are No Essential Differences in Morphogenesis and CK19 Protein Expression between Periportal and Perivenular Hepatocytes, As Well As between Normal and Ws/Ws Rat Hepatocytes}

Although there was no detectable CK19 protein (Figure 1, C and D) or CK19-immunopositive cells in the isolated hepatocytes, ${ }^{10}$ there was a possibility that the phenotypic changes in cultured hepatocytes described above were because of contaminated bile duct cells or liver stem cells in the initial cell fraction. Because bile duct cells and stem cells are present in the periportal areas of the liver lobules, the perivenular areas should be devoid of these cells. Therefore, to test the possible contribution of contaminated cells to the appearance of bile duct markers, we selectively isolated perivenular and periportal hepatocytes by the digitonin infusion method ${ }^{19}$ and compared the morphogenesis and CK protein expression. As shown in Figure 2A, there was no difference between the perivenular hepatocytes in branching morphogenesis. Furthermore, the hepatocytes from both areas expressed bile duct-specific CK (CK19, CK20) to the same extent after being embedded within the collagen gel matrix (Figure 2B).

Although our results showed that mature hepatocytes could demonstrate a bile duct-like phenotype soon after culture, it is possible that hepatocytes might have transformed themselves to stem-like cells, such as oval cells, at least transiently. To address the possibility, we examined hepatocytes from c-kit mutant (Ws/Ws) rats, ${ }^{20}$ which were demonstrated to be almost defective in oval cell proliferation after application of hepatocarcinogenic pro-

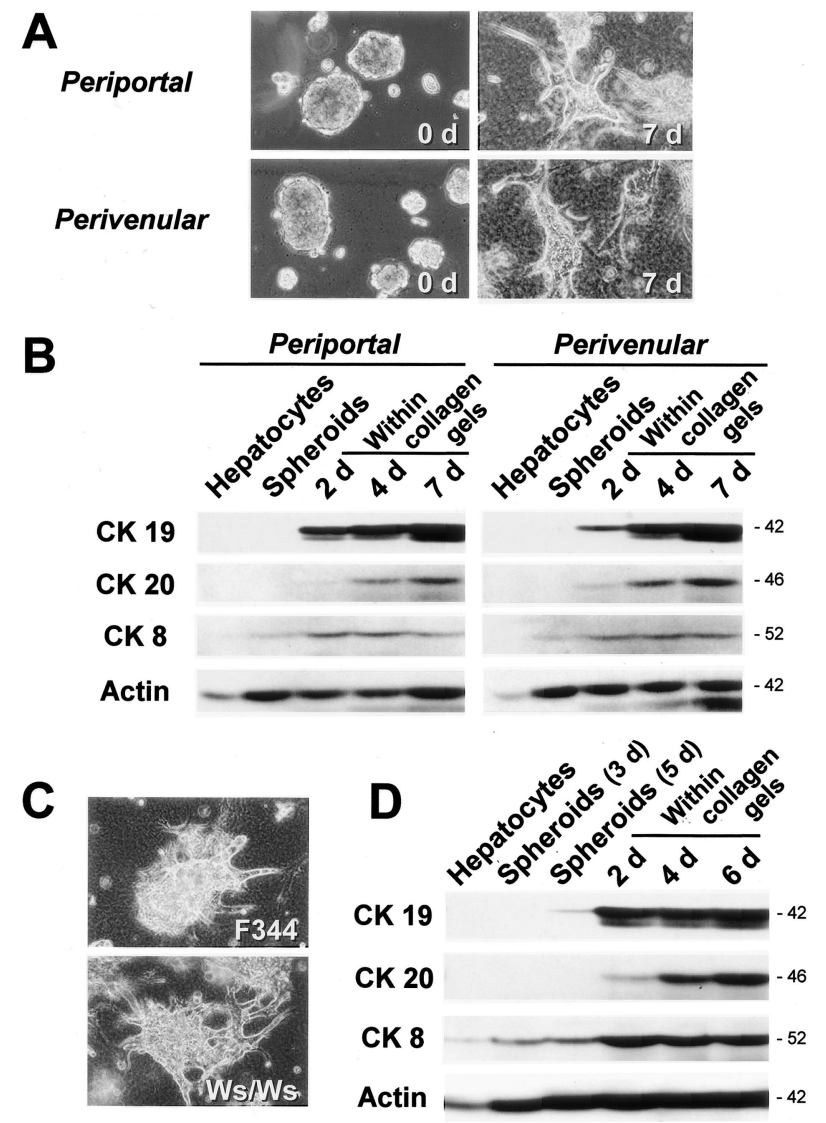

Figure 2. Branching morphogenesis and bile duct-specific CK expression of periportal and perivenular hepatocytes and Ws/Ws rat hepatocytes within a collagen gel matrix. Cells were cultured in the presence of insulin $\left(10^{-7}\right.$ $\mathrm{mol} / \mathrm{L})$ and EGF $(10 \mathrm{ng} / \mathrm{ml})$. A: Branching morphogenesis of periportal and perivenular hepatocytic spheroids. Phase-contrast microscopy. Original magnification, $\times 25$. B: Western blot analyses for the expression of CK19, CK20, $\mathrm{CK} 8$, and actin in cultured periportal and perivenular hepatocytes. C: Branching morphogenesis of normal (F344) and c-kit mutant (Ws/Ws) rat hepatocytes. Phase-contrast microscopy. Original magnification, $\times 25$. D: Western blot analyses for the expression of CK19, CK20, CK8, and actin in cultured Ws/Ws hepatocytes.

cedures. ${ }^{21} \mathrm{Ws} / \mathrm{Ws}$ hepatocytes also showed branching morphogenesis (Figure 2C) and protein expression of bile duct-specific CK similar to those in the control rats (Figure 2D), suggesting that bile duct-like differentiation of mature hepatocytes might not be dependent on oval cell transformation.

Gene Expression of Bile Duct-Specific Proteins, As Well As of Several Proteins Involved in Notch Signaling, but Not Delta-Like, Increases in Hepatocytes during Culture

Cultured hepatocytes fairly well maintained the expression of their differentiation markers, such as albumin, transthyretin, claudin2, and CYP2B2, for at least 2 weeks, whereas the expression of CYP8B1 gradually declined (Figure 3). However, the expression of CK19 mRNA appeared soon after culture, reached a plateau after 5 days in spheroids, and was maintained thereafter within the collagen gels (Figure 3, data not shown). The gene ex- 


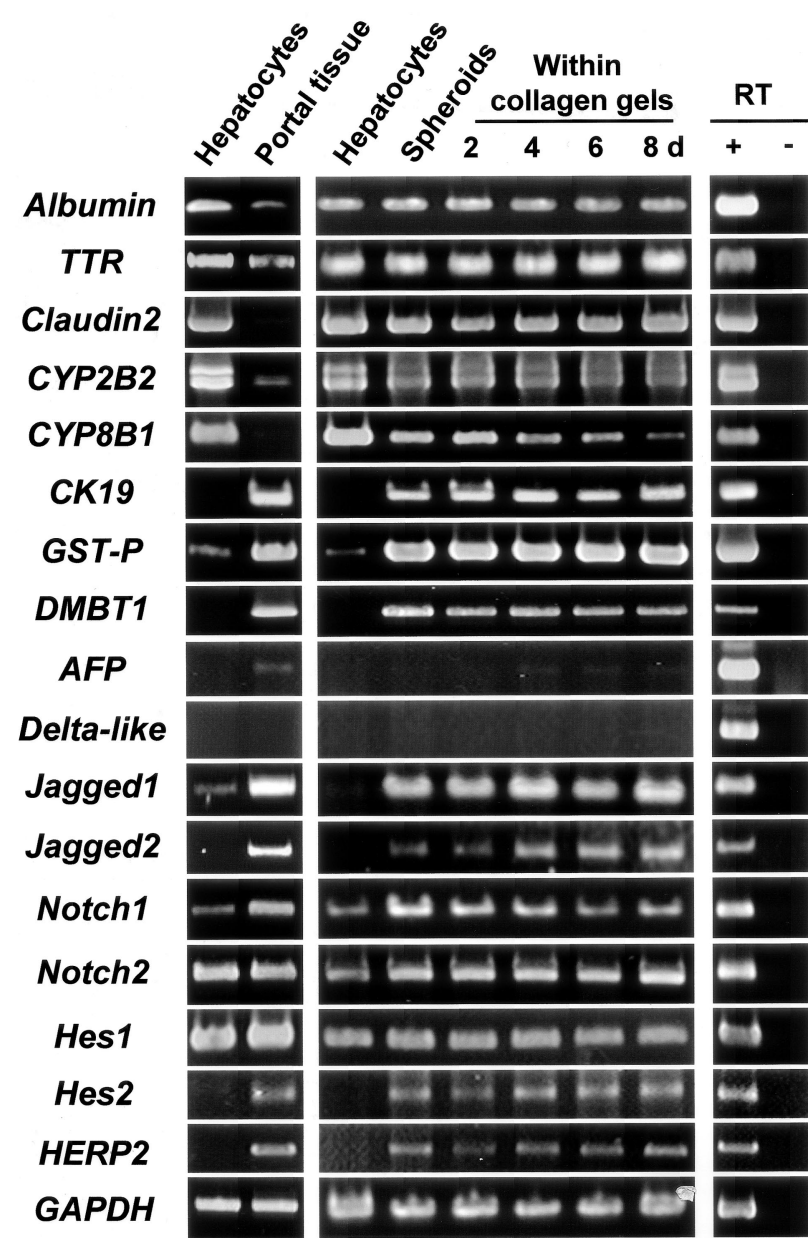

Figure 3. Time course of gene expression of various hepatocyte-, bile duct-, and oval cell-specific markers and the molecules involved in the Notch signaling pathway in cultured hepatocytes. Cells were cultured in the presence of insulin $\left(10^{-7} \mathrm{~mol} / \mathrm{L}\right)$ and EGF $(10 \mathrm{ng} / \mathrm{ml})$ and total RNA was extracted. RT-PCR analyses for the expression of albumin, transthyretin (TTR), claudin2, CYP2B2, CYP8B1, CK19, glutathione $S$-transferase placental form (GST-P), DMBT1, AFP, Delta-like, Notch ligands (Jagged1 and Jagged2), Notch receptors (Notch1 and Notch2), and primary Notch targets (Hes1, Hes2, HERP2). Comparison of gene expression between freshly isolated hepatocytes and the portal tissue containing bile ducts is shown at the left. For control, reverse transcriptase was omitted from the reaction mixture for each primer set with hepatocyte RNA (albumin, transthyretin, claudin2, CYP2B2, and CYP8B1), portal tissue RNA (CK19, GST-P, DMBT1, Jagged1, Jagged2, Notch1, Notch2, Hes1, Hes2, HERP2, and GAPDH), or E17.5 fetal liver RNA (AFP and Delta-like) as a template (right). GAPDH expression was assessed for the quality and quantity of each template RNA

pression of another bile duct marker, GST-P, ${ }^{29}$ also dramatically increased and persisted in cultured hepatocytes (Figure 3). Although DMBT1 protein has been reported to be positive in atypical ductular reaction and negative in normal hepatocytes and bile ducts, ${ }^{23}$ its mRNA was clearly detected in normal portal tissues (Figure 3). Notably, DMBT1 gene expression emerged in cultured hepatocytes (Figure 3). The aberrant expression of the DMBT1 gene in hepatocytes also took place in monolayer culture on collagen-coated dishes (Figure 4). As shown in a previous study, ${ }^{30}$ the major form of AFP mRNA (2.1 kb), which was undetectable in adult hepatocytes, was expressed in portal tissues containing bile ducts, although the expression level was much lower than that of the fetal liver (Figure 3). The AFP mRNA
A
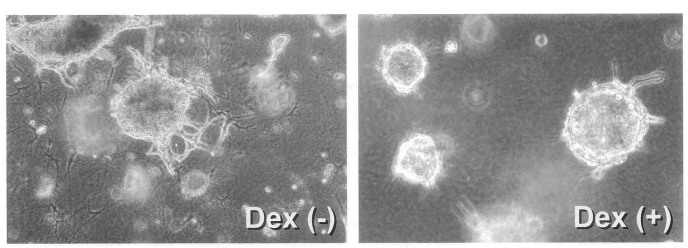

B

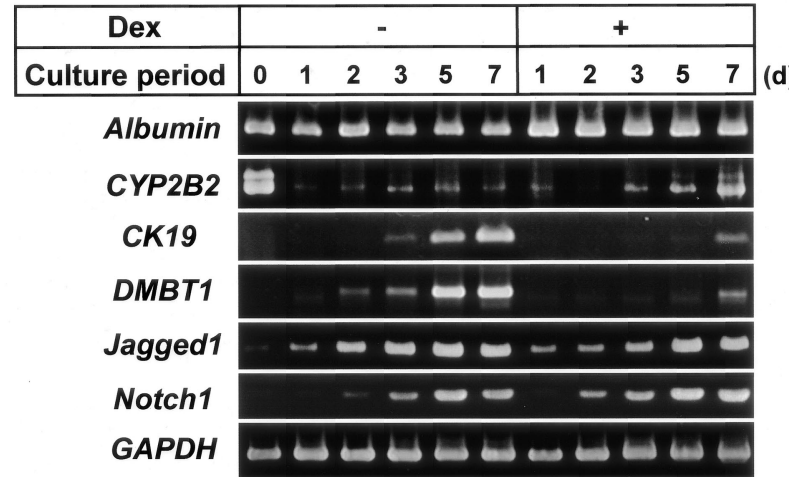

Figure 4. Effects of dexamethasone (Dex) on the morphogenesis of hepatocytic spheroids within a collagen gel matrix and gene expression of several differentiation markers. Hepatocytes were cultured in the presence of insulin $\left(10^{-7} \mathrm{~mol} / \mathrm{L}\right)$ and EGF $(10 \mathrm{ng} / \mathrm{ml})$, with or without Dex $(10 \mu \mathrm{mol} / \mathrm{L})$. A Phase-contrast microscopy of spheroid morphology cultured for 7 days within the gels. Original magnification, $\times 25$. B: RT-PCR analyses for the time course of expression of albumin, CYP2B2, CK19, DMBT1, Jagged1, and Notch1 in hepatocytes cultured on type I collagen-coated plastic dishes. GAPDH expression was assessed for the quality and quantity of each template RNA.

gradually increased in hepatocytes, but its expression level did not exceed that of portal tissues (Figure 3).

Since it has been recently shown that Delta-like or Dlk, a homologue of Drosophila Delta protein, is specifically expressed in oval cells and hepatoblasts, ${ }^{16,17}$ we examined whether Delta-like mRNA was expressed in cultured hepatocytes when they began to show bile duct markers. Consistent with previous reports, ${ }^{16,17,31}$ Delta-like gene was not expressed in the adult hepatocytes and portal tissue, but it was highly expressed in the fetal liver (Figure 3). Delta-like mRNA was not detected in cultured hepatocytes, suggesting that hepatocytes might not show an oval cell-like or hepatoblastic phenotype after maturation (Figure 3).

We also analyzed gene expression of the other ligands and receptors of the Notch signaling pathway, since it has been reported that the pathway is important in the development of intrahepatic bile ducts. ${ }^{18}$ Although gene expression of Jagged1, Jagged2, and Notch1 was higher in portal tissues as compared with hepatocytes, their expression was strongly induced in hepatocytes during spheroid formation, and the high expression levels were maintained after being embedded within the collagen gel matrix (Figure 3). The expression also occurred in monolayer cultures (Figure 4). In contrast, both hepatocytes and portal tissues expressed Notch2 mRNA to the same extent, and there was no change during culture (Figure 3). Although strong gene expression of Notch3 was seen in portal tissues, there was no detectable expression of the gene in hepatocytes either before or after culture (data not shown). 
To examine if the Notch signaling pathway was activated in cultured hepatocytes, we also performed RTPCR analyses for the expression of several primary Notch target genes. Among the Notch targets examined, we could not detect specific signals for Hes 3 and Hes5 gene expression in the liver (data not shown). Although strong Hes 1 gene expression was detected both in hepatocytes and portal tissues, there was no change in the expression in hepatocytes during culture (Figure 3). Although the HERP1 gene was strongly expressed in portal tissues, there was no detectable expression in hepatocytes either before or after culture (data not shown). The gene expression of Hes2 and HERP2 was observed in portal tissues, but not in freshly isolated hepatocytes. Their expression was, however, markedly induced and maintained at high levels in cultured hepatocytes (Figure 3).

\section{Dexamethasone Strongly Inhibits the Gene Expression of CK19 and DMBT1, As Well As Branching Morphogenesis, but Does Not Affect the Expression of Jagged 1 and Notch1}

Because glucocorticoids are known to play important roles in maintaining hepatocytic differentiation, ${ }^{14,32,33}$ we examined the effect of dexamethasone on cultured hepatocytes. Dexamethasone suppressed the formation of branching processes by spheroids and induced fluidcontaining cystic spaces in the center of the spheroids (Figure 4A). Consistent with previous reports, dexamethasone slightly increased the gene expression of albumin and CYP2B2 (Figure 4B). Dexamethasone strongly inhibited the expression of CK19 and DMBT1 genes, whereas it did not affect that of Jagged1 and Notch1 genes (Figure 4B).

\section{The Hepatocytic Expression of CK19 and DMBT1, but Not Jagged1 and Notch1, Is EGF-Dependent}

To explore the mechanism of the expression of bile duct markers by cultured hepatocytes, we examined the differential effects of EGF and insulin on gene expression of these proteins in monolayer cultured hepatocytes. Gene expression of CK19 and DMBT1 took place when EGF, not insulin, was present in the medium (Figure 5A). In contrast, gene expression of Jagged 1 and Notch1 was completely independent of these factors (Figure 5A). Then we examined which signaling pathways stimulated by EGF were involved in the gene expression of CK19 and DMBT1 by experiments using the MEK1 inhibitor PD98059 and the PI 3 kinase inhibitor LY294002. The gene expression of CK19 was inhibited by both reagents, although more strongly by LY294002 (Figure 5B). In contrast, DMBT1 gene expression was only slightly inhibited by PD98059, and not affected by LY294002 (Figure 5B). Neither inhibitor affected the expression of Jagged 1 and Notch1 genes (Figure 5B).

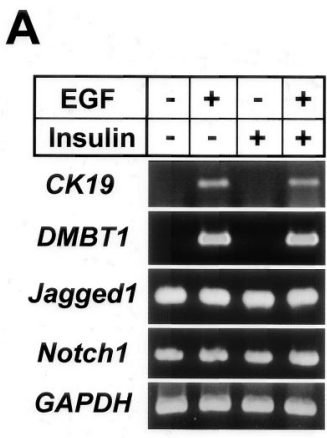

B

Figure 5. Effects of EGF, insulin, and signal transduction inhibitors on gene expression of bile duct markers in hepatocytes. Hepatocytes were cultured on type I collagen-coated plastic dishes for 4 days. A, B: RT-PCR analyses for the expression of CK19, DMBT1, Jagged1, and Notch1. A: Effects of EGF (10 $\mathrm{ng} / \mathrm{ml})$, insulin $\left(10^{-7} \mathrm{~mol} / \mathrm{L}\right)$, or both on the gene expression. B: RT-PCR analyses of the effects of PD98059 (mitogen-activated protein kinase 1 inhibitor) and LY294002 (PI 3-kinase inhibitor) on gene expression in the presence of EGF $(10 \mathrm{ng} / \mathrm{ml})$. GAPDH expression was assessed for the quality and quantity of each template RNA.

\section{Both Branching Morphogenesis and CK19 Protein Expression of Hepatocytes Are Enhanced by Increasing Protein Tyrosine Phosphorylation Levels by Orthovanadate and Inhibited by the MEK and PI $3 K$ Inhibitors}

The above data suggested that protein tyrosine phosphorylation pathways might be important in the branching morphogenesis and CK19 protein expression of cultured hepatocytes. To further test the possibility, spheroids were cultured with OV, a protein tyrosine phosphatase inhibitor that is known to increase the levels of protein tyrosine phosphorylation of cellular proteins, including those involved in the insulin and EGF pathways. In fact, OV markedly enhanced branching morphogenesis in the presence of insulin and EGF (Figure 6A). OV did not exert any morphogenetic effects when used alone or in combination with EGF (Figure 6B). On the other hand, when insulin was present, OV enhanced morphogenesis, which was further stimulated by the addition of EGF (Figure 6B), indicating that insulin was a prerequisite factor for branching morphogenesis of cultured hepatocytes, as we suggested in our previous study. ${ }^{10}$

OV enhanced CK19 protein expression in a dosedependent manner (Figure $6 \mathrm{C}$ ), whereas it did not significantly affect the expression of CK8 (Figure 7, B and C). In contrast to the effect on morphogenesis, this effect on CK19 protein expression was dependent on EGF, but not insulin (data not shown), which was consistent with the previous RT-PCR data (Figure 5A). As expected, OV increased tyrosine phosphorylation of cellular proteins, which appeared to be parallel to the increase in CK19 (Figure 6C).

To examine whether the growth of hepatocytes is required for the branching morphogenesis with CK19 expression, we analyzed PCNA expression during the process. Hepatocytes underwent robust transient cell growth on Primaria dishes when they formed spheroidal aggregates, but after being embedded within the collagen gel 
A

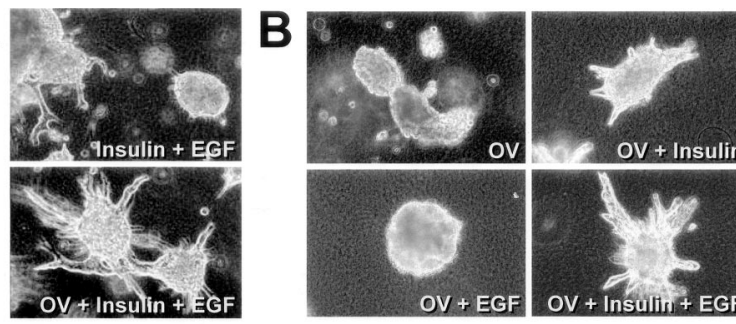

C
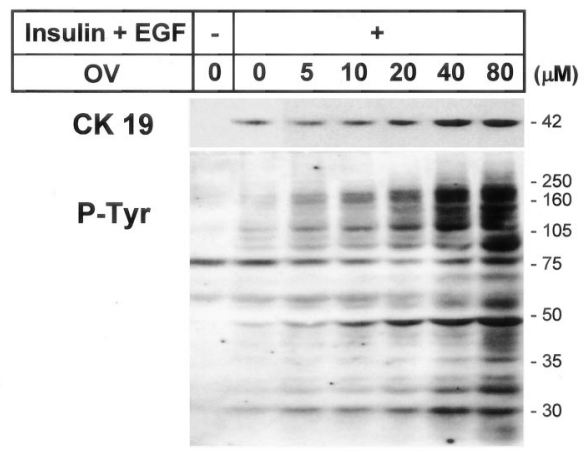

D

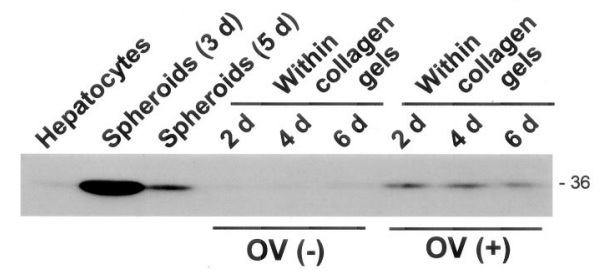

Figure 6. Effects of sodium orthovanadate (OV) on branching morphogenesis and CK19 expression of cultured hepatocytes. Hepatocytic spheroids were cultured within a type I collagen gel matrix for 7 days (A) or 4 days (B) in the presence of insulin $\left(10^{-7} \mathrm{~mol} / \mathrm{L}\right)$, EGF $(10 \mathrm{ng} / \mathrm{ml})$, or sodium orthovanadate $(\mathrm{OV}, 40 \mu \mathrm{mol} / \mathrm{L})$. A, B: Phase-contrast microscopy. Original magnification, $\times 25$. C: Western blot analyses for CK19- and tyrosine-phosphorylated proteins. D: Western blot analysis for PCNA

matrix, overall cell growth returned to basal levels (Figure $6 \mathrm{D})$. However, the stimulating effect of OV on morphogenesis was associated with an increase in PCNA expression (Figure 6D), suggesting that cell growth played an important role in branching morphogenesis.

To further examine the involvement of specific protein tyrosine phosphorylation pathways stimulated by insulin and EGF, we tested the effects of PD98059 and LY294002 on morphogenesis and CK19 protein expression within the gels. Both inhibitors blocked branching morphogenesis in the absence (data not shown) or presence of OV (Figure 7A). In agreement with the RT-PCR data shown above (Figure 5B), PD98059 inhibited both CK19 protein expression and ERK phosphorylation, which were induced by OV (Figure 7B). Likewise, LY294002 inhibited both CK19 protein expression and Akt phosphorylation (Figure 7C). In contrast, the expression of CK8 protein was not affected by these inhibitors (Figure 7, B and C).

\section{Hepatocytes Form Ductular Structures with Basement Membranes within the Collagen Matrix after Long-Term Cultures}

In our previous study, ${ }^{10}$ we demonstrated tubular structures lined by microvilli in the branching processes 7
A
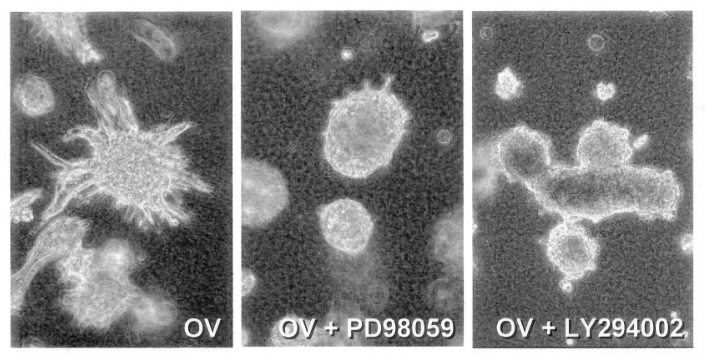

B
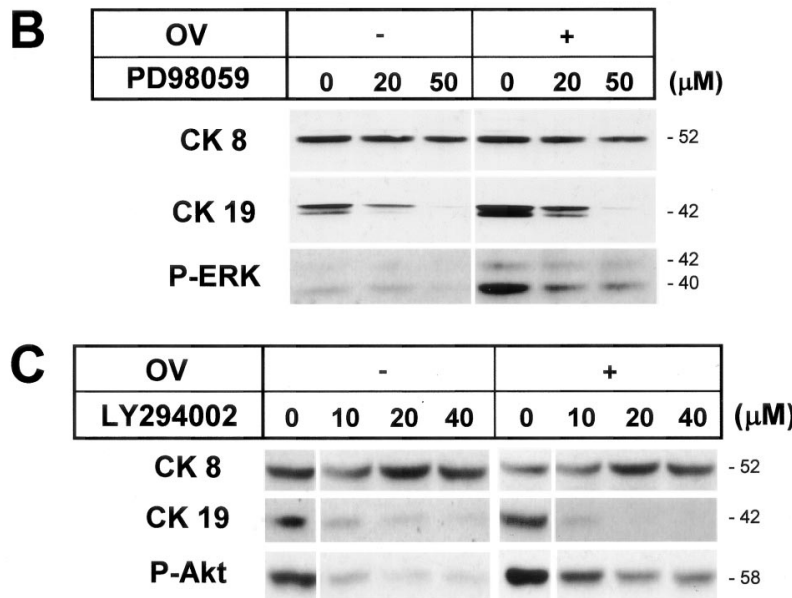

Figure 7. Effects of signal transduction inhibitors on branching morphogenesis and CK expression of cultured hepatocytes. Spheroidal aggregates were cultured within a type I collagen gel matrix for 7 days $(\mathbf{A})$ or 4 days $(\mathbf{B}, \mathbf{C})$ in a medium supplemented with insulin $\left(10^{-7} \mathrm{~mol} / \mathrm{L}\right)$ and EGF $(10 \mathrm{ng} / \mathrm{ml})$. A: Phase-contrast microscopy showing the effects of PD98059 $(50 \mu \mathrm{mol} / \mathrm{L})$ or LY294002 $(40 \mu \mathrm{mol} / \mathrm{L})$ in the presence of orthovanadate (OV, $40 \mu \mathrm{mol} / \mathrm{L})$. Original magnification, $\times 25$. B, C: Western blot analyses for the effects of PD98059 (B) or LY294002 (C) on expression of CK8, CK19, phosphorylated ERK (B), and phosphorylated Akt $(\mathbf{C})$.

days after culture, but we did not observe basement membranes around them. Because longer cultures might be necessary for basement membrane formation, we extended the culture period. Cells could be maintained at least for several months, if the gels did not detach from the dishes because of gradual shrinkage. After 3 weeks, many of the branching ductular processes began to dilate, and some became cystic, apparently because of fluid accumulation (Figure 8A). Thereafter, cell aggregates and processes became more ductular or microcystic (Figure 8B). H\&E-stained sections revealed that they were composed of many round ductular structures of various sizes (Figure 9, A and D). Electron microscopic observation demonstrated the presence of inchoate ductular structures surrounded by thin basement membranes after 25 days (Figure 8, C and D). After longer culture periods, the ductular structures became more mature with well-formed basement membranes (Figure 8, $E$ and $F$ ).

Immunocytochemically, although cells gradually lost albumin expression (Figure 9, B and E), they continued to express CK19 (Figure 9, C and F). Cells were also positive for CK7, another bile duct-specific CK (Figure 9G). Furthermore, apical surfaces of some of the dilated lumens contained Dolichos biflorus agglutinin-binding sites (Figure $9 \mathrm{H}$ ), which is a phenotypic characteristic of normal rat bile ducts. ${ }^{34}$ The extracellular matrix around the 


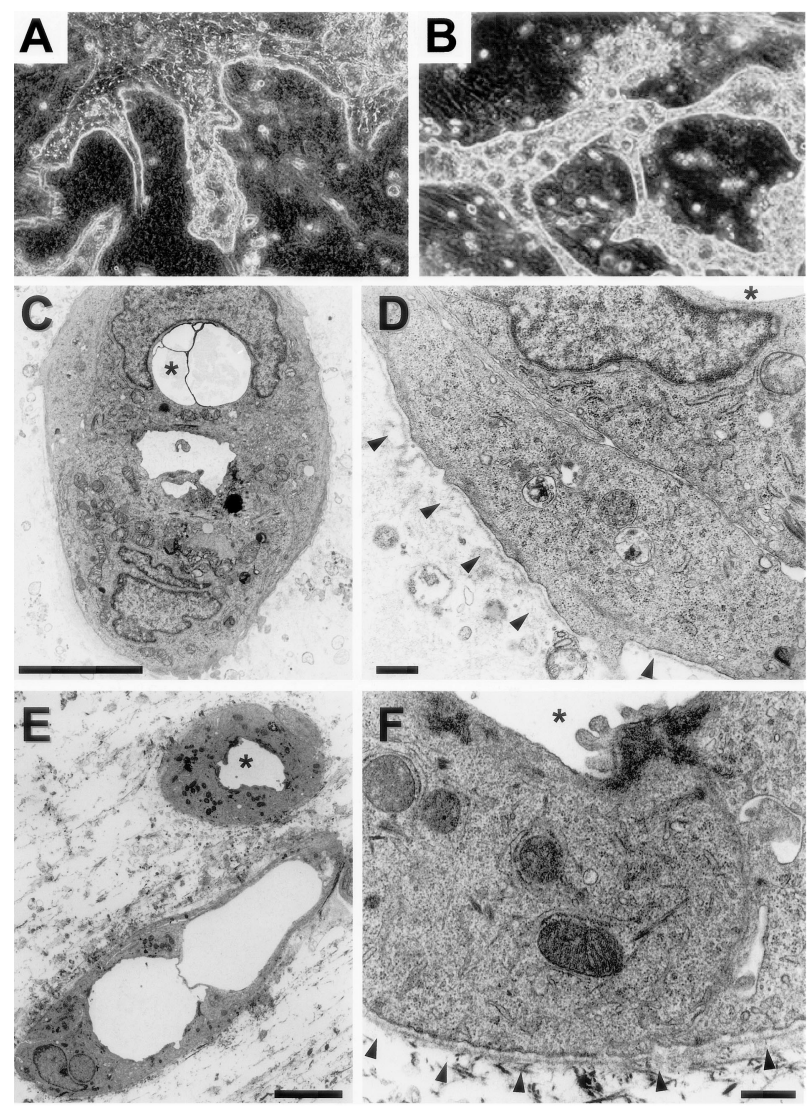

Figure 8. Bile duct-like morphology of hepatocytic aggregates after longterm culture. Spheroidal aggregates were cultured within a collagen ge matrix for 21 days $(\mathbf{A}), 25$ days $(\mathbf{C}, \mathbf{D})$, or 90 days $(\mathbf{B}, \mathbf{E}, \mathbf{F})$ in the presence of insulin $\left(10^{-7} \mathrm{~mol} / \mathrm{L}\right)$ and EGF $(10 \mathrm{ng} / \mathrm{ml})$. A, B: Phase-contrast microscopy. Original magnification, $\times 25$. C-F: Electron microscopy. The asterisks denote a lumen of the same ductular structure. Basement membranes are indicated by triangles in $\mathbf{D}$ and $\mathbf{F}$. Scale bars: $5 \mu \mathrm{m}(\mathbf{C}, \mathbf{E}), 0.5 \mu \mathrm{m}(\mathbf{D}, \mathbf{F})$.

ductular structures contained laminin (Figure 9l), as well as type IV collagen (Figure 9J). Most cells expressed Jagged 1 and Notch1 proteins, suggesting that each cell expressed both the ligands and receptors (Figure 9, K and $\mathrm{L})$.

\section{Discussion}

In this study, we showed that hepatocytes expressed several bile duct markers soon after culture and formed small ductular structures composed of a single cell layer and a central lumen, which were surrounded by a laminin-rich matrix and distinct basal membranes, within a collagen gel matrix after long-term cultures. Contrary to the widely accepted notion that the phenotype of hepatocytes is fixed, ${ }^{5,6}$ our results, together with other investigators' observations, ${ }^{11,12,14,15}$ strongly suggest that hepatocytes could change their phenotype to that of bile duct cells even after fully maturing.

The possibility that there were contaminated bile duct cells in the initial hepatocyte preparation seems to be unlikely, because neither CK19-positive cells, ${ }^{10}$ CK19 mRNA, nor CK19 protein were detected in the samples from the isolated hepatocyte fraction. Furthermore, our findings of isolated perivenular hepatocytes showing similar bile duct-like differentiation soon after culture further confirmed that the phenotypic change was not dependent on the presence of contaminated bile duct cells. It might also be argued that a small number of putative liver stem cells, which might be present in the hepatocytic preparation, selectively proliferated and differentiated into bile duct cells. However, this possibility is also unlikely, because these stem cells are thought to present preferentially in the periportal area that was destroyed by digitonin infusion.

Bile ductular differentiation of hepatocytes has also been described in several reports of extrahepatic transplantation of hepatocytes. Jirtle and colleagues ${ }^{35}$ observed bile ductular structures in hepatocyte transplants within the dorsal fascia of partially hepatectomized rats. Fogli and colleagues ${ }^{36}$ reported that proliferating hepatocytes, which were isolated at 24 hours after a partial hepatectomy, formed ductules in the spleen. Furthermore, Hillan and colleagues ${ }^{37}$ performed intrasplenic transplantation of hepatocytes and common bile duct ligation at the same time and reported that most of the transplanted hepatocytes became ductular. We also performed experiments in which hepatocytic aggregates cultured for 10 days ( 5 days on Primaria dishes and then 5 days within collagen gels) were transplanted into the splenic parenchyma, and found that the majority of the transplanted hepatocytes showed a ductular morphology after 1 or 2 weeks (Nishikawa et al, unpublished observation). These data indicate that hepatocytes can transform into bile duct-like cells under certain cellular and environmental conditions.

Generation of bile duct-like cells from differentiated hepatocytes may be explained by two distinct mechanisms: transdifferentiation (direct lineage conversion through an otherwise dormant differentiation program) or dedifferentiation (indirect lineage conversion via differentiation to a more primitive, stem-like cell and redifferentiation to another cell type). ${ }^{38}$ Oval cells and periductal stem cells have been proposed to constitute the putative stem cell system of the liver. ${ }^{4-6}$ Although the presence and significance of periductal stem cells are still controversial, ${ }^{39}$ there has been ample evidence showing that oval cells may be transit-amplifying cells that ultimately differentiate into hepatocytes or bile duct cells in some cases of severe liver injury. It has been recently reported that rat oval cells specifically express Delta-like protein that belongs to the EGF-like homeotic protein family. ${ }^{16}$ Interestingly, the same protein has also been shown to be expressed in mouse hepatoblasts that are the sources of both hepatocytic and bile duct lineages. ${ }^{17}$ Our experiments demonstrated that cultured hepatocytes did not express Delta-like mRNA during bile duct-like differentiation, suggesting that hepatocytes might not undergo dedifferentiation after maturation. This is consistent with the recent report by Wang and colleagues, ${ }^{40}$ which has demonstrated that dedifferentiation of hepatocytes to oval cells does not occur in vivo in mouse liver repopulation experiments. Furthermore, hepatocytes from the 

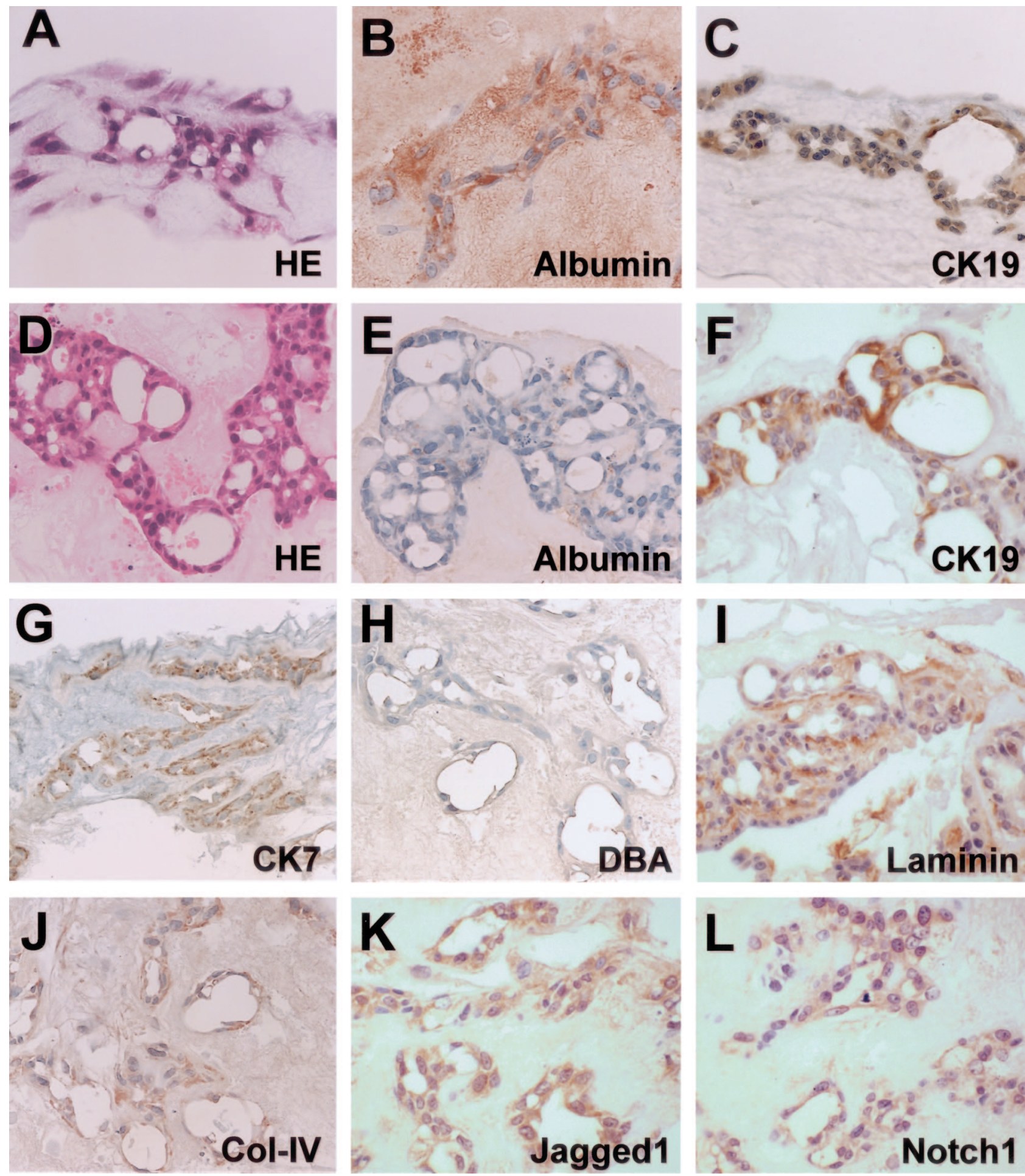

Figure 9. Bile duct-like phenotype of hepatocytic aggregates after long-term culture. Spheroidal aggregates were cultured within a type I collagen gel matrix for 25 days $(\mathbf{A}-\mathbf{C})$ or 90 days $(\mathbf{D}-\mathbf{L})$ in the presence of insulin $\left(10^{-7} \mathrm{~mol} / \mathrm{L}\right)$ and EGF $(10 \mathrm{ng} / \mathrm{ml})$. A, D: H\&E staining. B, C, E-G, I-L: Immunocytochemistry for albumin (B, E), CK19 (C, F), cytokeratin 7 (CK7) (G), laminin (I), type IV collagen (Col-IV) (J), Jagged1 (K), and Notch1 (L). H: Lectin cytochemistry for Dolichos biflorus agglutinin (DBA). Original magnifications, $\times 100$.

Ws/Ws rats, in which c-kit tyrosine kinase activity is severely impaired because of a deletion in the tyrosine kinase domain, ${ }^{20}$ showed phenotypic changes almost identical to those seen in normal rats. Expressing stem cell factor and its receptor c-kit, ${ }^{41}$ oval cells share some characteristics with hematopoietic stem cells, and c-kitmediated signal transduction is considered to be crucial in the development of oval cells. ${ }^{21}$ Thus, our in vitro data suggest that mature hepatocytes might change their phenotype to those of bile duct-like cells through the trans- 
differentiation mechanism, although further studies will be required to confirm this.

Our results provide insight into the mechanisms of the atypical ductular reaction often observed in chronic liver disease. Although the possibility of bile duct metaplasia of stem cells residing in the adult liver is not excluded, ${ }^{3,4}$ the emergence of bile ductules can be explained by transdifferentiation of mature hepatocytes, ie, ductular metaplasia. ${ }^{1,2}$ In the atypical ductular reaction, newly formed ductules are usually seen among regenerating hepatocytes along the inflamed portal tissue, where progressive deposition of the collagenous matrix and the release of various growth factors and cytokines take place. During liver organogenesis, it has been shown that immature hepatocytes form bile ductules along the developing portal connective tissue. ${ }^{42}$ The collagenous matrix might also be an inducer of bile duct differentiation of mature hepatocytes. Our in vitro model of the ductular metaplasia of hepatocytes may be a useful tool for the further understanding of the processes of the progression of chronic liver damage because of a decrease in functional hepatocytes and possible recovery from the damage by redifferentiation of ductular hepatocytes. Although it appears that prevention of portal inflammation and fibrosis is the most important means of maintaining hepatocytic differentiation in the liver, our study also suggested the significant role of corticosteroids, such as dexamethasone, in suppressing aberrant differentiation of hepatocytes toward bile duct-like cells. Similar observations have been made by Michalopoulos and colleagues ${ }^{14,33}$ in their organoid hepatocyte culture system.

We showed that gene expression of Jagged1, Jagged2, and Notch1 increased soon after culture, whereas expression of Notch2 was unchanged and Notch3 was undetectable in hepatocytes. Furthermore, our immunocytochemical study showed that almost all cells expressed both Jagged 1 and Notch1, indicating that each cell expresses Notch ligands and receptors. The Notch signaling pathway is known to be crucial in differentiation of many tissues. ${ }^{43}$ Jagged 1 has been identified as the defective gene in Alagille syndrome, a genetic disorder characterized by a symptomatic paucity of intrahepatic bile duct cells. ${ }^{25,26}$ Mice double heterozygous for Jagged1 and Notch2 have been reported to exhibit Alagille-like symptoms. ${ }^{44}$ Jagged/Notch interaction and subsequent Notch activation are considered to be essential in the differentiation of intrahepatic bile ducts during liver organogenesis. ${ }^{18,45}$ Recent reports have also shown that bile duct expression of Notch and its ligands, including Jagged1, is altered in chronic liver disease, suggesting important pathogenetic roles of the Notch signaling pathway. ${ }^{24,46,47}$

On ligand binding, the Notch receptor is processed by the regulated intramembrane proteolysis followed by translocation of the Notch intracellular domain (NICD) of the protein to the nucleus, where NICD forms a complex with a DNA binding protein (CBF), and binds to the promoters of several primary target genes, thereby regulating their transcription. ${ }^{43}$ Hes and HERP families are known to be regulated directly by NICD/CBF binding. ${ }^{43,48}$ The HERP family, called variously Hesr, HRT,
CHF, Hey, or gridlock, cooperates with Hes by forming Hes-HERP heterodimers. ${ }^{48,49}$ Our RT-PCR data of rapid induction of Hes2 and HERP2 in cultured hepatocytes suggest that activation of the Notch signaling pathway actually occurs in the process of hepatocytic transdifferentiaton. Interestingly, HERP2 expression has been demonstrated to be associated with tubular network formation by endothelial cells, ${ }^{50}$ highlighting a possible relationship between tubular morphogenesis and the Notch signaling. However, our experiments also showed that dexamethasone inhibited the expression of bile duct markers and branching morphogenesis, yet it did not affect the induction of Jagged1 and Notch1 gene expression, suggesting that the activation of Notch signaling itself is not sufficient to induce bile duct-like differentiation of hepatocytes.

Cellular pathways regulated by protein tyrosine phosphorylation are important in growth and differentiation of many types of cells, ${ }^{51}$ including bile duct cells. ${ }^{52,53}$ The present study demonstrated that CK19 expression was dependent on EGF, whereas branching morphogenesis required insulin and was enhanced by EGF, suggesting that bile duct-like differentiation of mature hepatocytes is under the influence of insulin and EGF signaling pathways. The differentiation was further enhanced by OV, which caused a sustained increase in tyrosine phosphorylation of cellular proteins because of its inhibitory action on protein tyrosine phosphatases. ${ }^{54,55}$ OV has been shown to activate many receptor tyrosine kinases, including EGF, insulin, and hepatocyte growth factor receptors, ${ }^{55}$ which then activate downstream signaling pathways, such as Ras-Raf-MEK1-ERK and PI 3-kinase-Akt. Our experiments using the specific inhibitors of MEK1 and PI 3-kinase suggested their involvement in both branching morphogenesis and the expression of bile duct-specific CK19. Recent works by other investigators have shown that these pathways play important roles in branching morphogenesis in various types of epithelial cells. ${ }^{56-58}$ Although there have been several lines of evidence suggesting the presence of interaction between the Notch and protein tyrosine phosphorylation pathways, ${ }^{59-61}$ our study showed that Jagged1 and Notch1 expression by hepatocytes spontaneously took place after culture in the absence of the signals caused by insulin or EGF.

In summary, our study shows that hepatocytes differentiate toward bile duct-like cells in vitro, probably through the transdifferentiation mechanism, with the activation of the Notch signaling pathway, and that specific protein tyrosine phosphorylation pathways are involved in this process. Our results of phenotypic plasticity of hepatocytes in vitro may shed light on the understanding of the differentiation capacity of hepatocytes, as well as the nature of atypical ductular reaction in chronic liver disease.

\section{Acknowledgments}

We thank Ms. K. Ogasawara, S. Kosaka, S. Ito, R. Ito, A. Yagisawa, and S. Kudo for excellent technical assis- 
tance; Ms. E. Kumagai for secretarial help; and Dr. C. Taneno (Yoshizato Project, Japan Science and Technology Agency, Prefectural Institute of Industrial Science and Technology, Japan) for her advice on the digitonin infusion technique.

\section{References}

1. Desmet V, Roskams T, Van Eyken P: Ductular reaction in the liver. Pathol Res Pract 1995, 191:513-524

2. Popper $\mathrm{H}$ : The relation of mesenchymal cell products to hepatic epithelial system. Progress in Liver Diseases. Edited by Popper H, Schaffner F. Philadelphia, W. B. Saunders, 1990, pp 27-38

3. Haque S, Haruna Y, Saito K, Nalesnik MA, Atillasoy E, Thung SN, Gerber MA: Identification of bipotential progenitor cells in human liver regeneration. Lab Invest 1996, 75:699-705

4. Theise ND, Saxena R, Portmann BC, Thung SN, Yee H, Chiriboga L, Kumar A, Crawford JM: The canals of Hering and hepatic stem cells in humans. Hepatology 1999, 30:1425-1433

5. Alison M: Liver stem cells: a two compartment system. Curr Opin Cell Biol 1998, 10:710-715

6. Sell S: Heterogeneity and plasticity of hepatocyte lineage cells. Hepatology 2001, 33:738-750

7. Overturf K, al-Dhalimy M, Ou CN, Finegold M, Grompe M: Serial transplantation reveals the stem-cell-like regenerative potential of adult mouse hepatocytes. Am J Pathol 1997, 151:1273-1280

8. Rhim JA, Sandgren EP, Degen JL, Palmiter RD, Brinster RL: Replacement of diseased mouse liver by hepatic cell transplantation. Science 1994, 263:1149-1152

9. Sandgren EP, Palmiter RD, Heckel JL, Daugherty CC, Brinster RL, Degen JL: Complete hepatic regeneration after somatic deletion of an albumin-plasminogen activator transgene. Cell 1991, 66:245-256

10. Nishikawa Y, Tokusashi Y, Kadohama T, Nishimori H, Ogawa K: Hepatocytic cells form bile duct-like structures within a three-dimensional collagen gel matrix. Exp Cell Res 1996, 223:357-371

11. Block GD, Locker J, Bowen WC, Petersen BE, Katyal S, Strom SC Riley T, Howard TA, Michalopoulos GK: Population expansion, clonal growth, and specific differentiation patterns in primary cultures of hepatocytes induced by HGF/SF, EGF and TGF alpha in a chemically defined (HGM) medium. J Cell Biol 1996, 132:1133-1149

12. Cable EE, Isom HC: Exposure of primary rat hepatocytes in long-term DMSO culture to selected transition metals induces hepatocyte proliferation and formation of duct-like structures. Hepatology 1997, 26:1444-1457

13. Michalopoulos GK, Bowen WC, Zajac VF, Beer-Stolz D, Watkins S, Kostrubsky V, Strom SC: Morphogenetic events in mixed cultures of rat hepatocytes and nonparenchymal cells maintained in biological matrices in the presence of hepatocyte growth factor and epidermal growth factor. Hepatology 1999, 29:90-100

14. Michalopoulos GK, Bowen WC, Mule K, Stolz DB: Histological organization in hepatocyte organoid cultures. Am J Pathol 2001, 159:1877-1887

15. Michalopoulos GK, Bowen WC, Mule K, Lopez-Talavera JC, Mars W: Hepatocytes undergo phenotypic transformation to biliary epithelium in organoid cultures. Hepatology 2002, 36:278-283

16. Jensen $\mathrm{CH}$, Jauho El, Santoni-Rugiu E, Holmskov U, Teisner B, Tygstrup N, Bisgaard HC: Transit-amplifying ductular (oval) cells and their hepatocytic progeny are characterized by a novel and distinctive expression of delta-like protein/preadipocyte factor 1/fetal antigen 1. Am J Pathol 2004, 164:1347-1359

17. Tanimizu N, Nishikawa M, Saito H, Tsujimura T, Miyajima A: Isolation of hepatoblasts based on the expression of Dlk/Pref-1. J Cell Sci 2003, 116:1775-1786

18. Crosby HA, Nijjar SS, de Goyet Jde V, Kelly DA, Strain AJ: Progenitor cells of the biliary epithelial cell lineage. Semin Cell Dev Biol 2002, 13:397-403

19. Lindros KO, Penttila KE: Digitonin-collagenase perfusion for efficient separation of periportal or perivenous hepatocytes. Biochem J 1985, 228:757-760

20. Tsujimura T, Hirota S, Nomura S, Niwa Y, Yamazaki M, Tono T, Morii E, Kim HM, Kondo K, Nishimune Y, Kitamura Y: Characterization of
Ws mutant allele of rats: a 12-base deletion in tyrosine kinase domain of c-kit gene. Blood 1991, 78:1942-1946

21. Matsusaka S, Tsujimura T, Toyosaka A, Nakasho K, Sugihara A Okamoto E, Uematsu K, Terada N: Role of c-kit receptor tyrosine kinase in development of oval cells in the rat 2-acetylaminofluorene/ partial hepatectomy model. Hepatology 1999, 29:670-676

22. Ohmura T, Enomoto K, Satoh H, Sawada N, Mori M: Establishment of a novel monoclonal antibody, SE-1, which specifically reacts with rat hepatic sinusoidal endothelial cells. J Histochem Cytochem 1993, 41:1253-1257

23. Bisgaard HC, Holmskov U, Santoni-Rugiu E, Nagy P, Nielsen O, Ott $P$, Hage E, Dalhoff K, Rasmussen LJ, Tygstrup N: Heterogeneity of ductular reactions in adult rat and human liver revealed by novel expression of deleted in malignant brain tumor 1. Am J Pathol 2002, 161:1187-1198

24. Louis AA, Van Eyken P, Haber BA, Hicks C, Weinmaster G, Taub R, Rand EB: Hepatic Jagged1 expression studies. Hepatology 1999, 30:1269-1275

25. Li L, Krantz ID, Deng Y, Genin A, Banta AB, Collins CC, Qi M, Trask BJ, Kuo WL, Cochran J, Costa T, Pierpont ME, Rand EB, Piccoli DA, Hood L, Spinner NB: Alagille syndrome is caused by mutations in human Jagged1, which encodes a ligand for Notch1. Nat Genet 1997, 16:243-251

26. Oda T, Elkahloun AG, Pike BL, Okajima K, Krantz ID, Genin A, Piccol DA, Meltzer PS, Spinner NB, Collins FS, Chandrasekharappa SC: Mutations in the human Jagged1 gene are responsible for Alagille syndrome. Nat Genet 1997, 16:235-242

27. Miura K, Nagai H, Ueno Y, Goto T, Mikami K, Nakane K, Yoneyama K, Watanabe D, Terada K, Sugiyama T, Imai K, Senoo H, Watanabe S: Epimorphin is involved in differentiation of rat hepatic stem-like cells through cell-cell contact. Biochem Biophys Res Commun 2003, 311:415-423

28. Faa G, Van Eyken P, Roskams T, Miyazaki H, Serreli S, Ambu R, Desmet $\mathrm{VJ}$ : Expression of cytokeratin 20 in developing rat liver and in experimental models of ductular and oval cell proliferation. J Hepatol 1998, 29:628-633

29. Lupp A, Anschutz T, Lindstrom-Seppa P, Muller D: Developmental changes in glutathione S-transferase isoforms expression and activity in intrasplenic fetal liver tissue transplants in rats. Exp Toxicol Pathol 2003, 55:107-119

30. Lemire JM, Fausto N: Multiple alpha-fetoprotein RNAs in adult rat liver: cell type-specific expression and differential regulation. Cancer Res 1991, 51:4656-4664

31. Stump G, Durrer A, Klein AL, Lutolf S, Suter U, Taylor V: Notch1 and its ligands Delta-like and Jagged are expressed and active in distinct cell populations in the postnatal mouse brain. Mech Dev 2002, 114:153-159

32. Shelly LL, Tynan W, Schmid W, Schutz G, Yeoh GC: Hepatocyte differentiation in vitro: initiation of tyrosine aminotransferase expression in cultured fetal rat hepatocytes. J Cell Biol 1989, 109:3403-3410

33. Michalopoulos GK, Bowen WC, Mule K, Luo J: HGF-, EGF-, and dexamethasone-induced gene expression patterns during formation of tissue in hepatic organoid cultures. Gene Expr 2003, 11:55-75

34. Itagaki S, Doi C, Mitsuoka T, Doi K: Histochemical study on the bile duct system of normal rats. Jikken Dobutsu 1990, 39:421-424

35. Jirtle RL, Biles C, Michalopoulos G: Morphologic and histochemical analysis of hepatocytes transplanted into syngeneic hosts. Am J Pathol 1980, 101:115-126

36. Fogli L, Cappellari L, Gorini P, Morsiani E: The origin of bile ductularlike structures after transplantation of regenerating hepatocytes into the spleen of syngeneic rats. Ital J Surg Sci 1987, 17:147-151

37. Hillan KJ, Burt AD, George WD, MacSween RN, Griffiths MR, Bradley JA: Intrasplenic hepatocyte transplantation in rats with experimental liver injury: morphological and morphometric studies. J Pathol 1989, 159:67-73

38. Wagers AJ, Weissman IL: Plasticity of adult stem cells. Cell 2004 116:639-648

39. Paku S, Schnur J, Nagy P, Thorgeirsson SS: Origin and structural evolution of the early proliferating oval cells in rat liver. Am J Pathol 2001, 158:1313-1323

40. Wang X, Foster M, Al-Dhalimy M, Lagasse E, Finegold M, Grompe M: The origin and liver repopulating capacity of murine oval cells. Proc Natl Acad Sci USA 2003, 100(Suppl 1):11881-11888

41. Fujio K, Evarts RP, Hu Z, Marsden ER, Thorgeirsson SS: Expression of 
stem cell factor and its receptor, c-kit, during liver regeneration from putative stem cells in adult rat. Lab Invest 1994, 70:511-516

42. Shiojiri N, Nagai Y: Preferential differentiation of the bile ducts along the portal vein in the development of mouse liver. Anat Embryol (Berl) 1992, 185:17-24

43. Artavanis-Tsakonas S, Rand MD, Lake RJ: Notch signaling: cell fate control and signal integration in development. Science 1999, 284:770-776

44. McCright B, Lozier J, Gridley T: A mouse model of Alagille syndrome: notch2 as a genetic modifier of Jag1 haploinsufficiency. Development 2002, 129:1075-1082

45. Tanimizu N, Miyajima A: Notch signaling controls hepatoblast differentiation by altering the expression of liver-enriched transcription factors. J Cell Sci 2004, 117:3165-3174

46. Nijiar SS, Crosby HA, Wallace L, Hubscher SG, Strain AJ: Notch receptor expression in adult human liver: a possible role in bile duct formation and hepatic neovascularization. Hepatology 2001, 34:1184-1192

47. Nijjar SS, Wallace L, Crosby HA, Hubscher SG, Strain AJ: Altered Notch ligand expression in human liver disease: further evidence for a role of the Notch signaling pathway in hepatic neovascularization and biliary ductular defects. Am J Pathol 2002, 160:1695-1703

48. Iso $T$, Sartorelli V, Chung G, Shichinohe T, Kedes L, Hamamori $Y$ : HERP, a new primary target of Notch regulated by ligand binding. Mol Cell Biol 2001, 21:6071-6079

49. Iso T, Sartorelli V, Poizat C, lezzi S, Wu HY, Chung G, Kedes L, Hamamori Y: HERP, a novel heterodimer partner of HES/E(spl) in Notch signaling. Mol Cell Biol 2001, 21:6080-6089

50. Henderson AM, Wang SJ, Taylor AC, Aitkenhead M, Hughes CC: The basic helix-loop-helix transcription factor HESR1 regulates endothelial cell tube formation. J Biol Chem 2001, 276:6169-6176

51. Hunter T: Signaling-2000 and beyond. Cell 2000, 100:113-127

52. Yokomuro S, Tsuji H, Lunz III JG, Sakamoto T, Ezure T, Murase N, Demetris AJ: Growth control of human biliary epithelial cells by interleukin 6, hepatocyte growth factor, transforming growth factor beta1, and activin $\mathrm{A}$ : comparison of a cholangiocarcinoma cell line with primary cultures of non-neoplastic biliary epithelial cells. Hepatology 2000, 32:26-35

53. Marucci L, Alpini G, Glaser SS, Alvaro D, Benedetti A, Francis $H$, Phinizy JL, Marzioni M, Mauldin J, Venter J, Baumann B, Ugili L, LeSage G: Taurocholate feeding prevents $\mathrm{CCl}$-induced damage of large cholangiocytes through PI3-kinase-dependent mechanism. Am J Physiol 2003, 284:G290-G301

54. Huyer G, Liu S, Kelly J, Moffat J, Payette P, Kennedy B, Tsaprailis G, Gresser MJ, Ramachandran C: Mechanism of inhibition of proteintyrosine phosphatases by vanadate and pervanadate. J Biol Chem 1997, 272:843-851

55. Nishikawa Y, Wang Z, Kerns J, Wilcox CS, Carr BI: Inhibition of hepatoma cell growth in vitro by arylating and non-arylating $\mathrm{K}$ vitamin analogs. Significance of protein tyrosine phosphatase inhibition. J Biol Chem 1999, 274:34803-34810

56. Karihaloo A, O'Rourke DA, Nickel C, Spokes K, Cantley LG: Differential MAPK pathways utilized for HGF- and EGF-dependent renal epithelial morphogenesis. J Biol Chem 2001, 276:9166-9173

57. Tang MJ, Cai Y, Tsai SJ, Wang YK, Dressler GR: Ureteric bud outgrowth in response to RET activation is mediated by phosphatidylinositol 3-kinase. Dev Biol 2002, 243:128-136

58. Larsen M, Hoffman MP, Sakai T, Neibaur JC, Mitchell JM, Yamada KM: Role of PI 3-kinase and PIP(3) in submandibular gland branching morphogenesis. Dev Biol 2003, 255:178-191

59. Fitzgerald $\mathrm{K}$, Harrington A, Leder P: Ras pathway signals are required for notch-mediated oncogenesis. Oncogene 2000, 19:4191-4198

60. Carmena A, Buff E, Halfon MS, Gisselbrecht S, Jimenez F, Baylies MK, Michelson AM: Reciprocal regulatory interactions between the Notch and Ras signaling pathways in the Drosophila embryonic mesoderm. Dev Biol 2002, 244:226-242

61. Weijzen S, Rizzo P, Braid M, Vaishnav R, Jonkheer SM, Zlobin A, Osborne BA, Gottipati S, Aster JC, Hahn WC, Rudolf M, Siziopikou K, Kast WM, Miele L: Activation of Notch-1 signaling maintains the neoplastic phenotype in human Ras-transformed cells. Nat Med 2002, 8:979-986 